\title{
DIETARY ASSESSMENT AND NUTRIENT INTAKE OF PREGNANT DIABETIC WOMEN FROM NAGPUR CITY
}

\author{
Sangita R. Meghal ${ }^{1}$ and Kalpana Jadhav ${ }^{2}$ \\ ${ }^{1}$ Research Fellow, Post Graduate Department of Home Science \\ Rashtrasant Tukadoji Maharaj Nagpur University, Nagpur \\ ${ }^{2}$ Professor and Head, Post Graduate Department of Home Science \\ Rashtrasant Tukadoji Maharaj Nagpur University, Nagpur
}

\begin{abstract}
:
The aim of the study was to conduct dietary assessment and to calculate nutrient intake of pregnant diabetic women. For present study, purposive random sampling technique was used to select the sample. By using this method, researcher selected total 500 pregnant diabetic women from Nagpur city. The data regarding nutrition was collected through dietary survey. Diabetic pregnant women get higher amount of calories $(2339 \pm 231.38$ Kcal), carbohydrates $(202.9 \pm 34.3 \mathrm{gm} /$ day) and fats $(42.33 \pm 10.6 \mathrm{gm} /$ day $)$ from their diet while they get less amount of proteins $(63.54 \pm 9.48$ $\mathrm{gm} /$ day), vitamin-A $(1509.11 \pm 775.53 \square \mathrm{g} /$ day $)$, vitamin $-B_{1}(0.053 \pm 0.045 \mathrm{mg} /$ day $)$, vitamin $-B_{2}(0.12 \pm 0.11 \mathrm{mg} /$ day $)$, vitamin-B $12 \quad(0.07 \pm 0.05 \square \mathrm{g} /$ day $)$, calcium $(557.02 \pm 28.26 \mathrm{mg} /$ day $)$, iron $(21.22 \pm 9.43 \mathrm{mg} /$ day $)$, magnesium $(105.57 \pm 17.15 \mathrm{mg} /$ day) and zinc $(7.42 \pm 1.98 \mathrm{mg} /$ day). It is suggested that Diabetic pregnant women should consult a dietician and get a weekly diet chart. The diet chart should be followed strictly; they should take timely breakfast and meals, should strictly avoid eating fast food and should use fruits and green leafy vegetables in their diet.
\end{abstract}

Key words :- Pregnant Diabetic Women; Nutrition, Diet

\section{INTRODUCTION:}

The nutritional status of pregnant mother is of exclusive place and importance for getting sound child. The health of pregnant woman is mostly depend on the diet she taken during pregnancy to delivery. It is evident that consuming the diet in a prescribed quantity not only keep pregnant woman healthy, but it also helps in easy and normal delivery. Hence, in the view of research, it is obvious to gain importance by the subject like health and nutrition of pregnant woman.

During pregnancy, optimal growth and the health of the fetus and mother are foremost. Thus, weight loss strategies have limited use because maternal energy restriction may adversely affect foetal growth and development (American Diabetes Association, 2002). Most women who have gestational diabetes give birth to healthy babies, specially when they keep their blood sugar under control, eat a healthy diet, get regular, moderate physical activity, and maintain a healthy weight. In some cases, though, the condition can affect the pregnancy. A healthy diet is one that includes a balance of foods from all the food groups, giving the nutrients, vitamins and minerals needed for a healthy pregnancy. For women with gestational diabetes, such a diet also helps to keep blood sugar levels in the healthy target range.

Rogozińska et al., (2015) found that nutritional manipulation in pregnancy based on diet or mixed approach do not appear to reduce the risk of GDM. Nutritional supplements show potential as agents for primary prevention of GDM. Pérez-Ferre et al., (2015) found that lifestyle intervention was effective for the prevention of glucose disorders in women with prior GDM. Body weight gain and an unhealthy fat intake pattern were found to be the most predictive factors for the development of glucose disorders.

Although, nutritional status during pregnancy is important in a view of health of pregnant woman and her fetus, however, it is evident that pregnant diabetic women are not aware regarding necessary information of this issue. For giving birth to healthy child, it is necessary for pregnant diabetic women to gain proper health and nutrition. Although it is true but to achieve this, they have to face various problems and obstacles. Hence, this study was carried out to know the dietary intake of pregnant diabetic women and to carry out their dietary assessment. The study have following objectives-

1) To study food habits and meal pattern of pregnant diabetic women 
2) To calculate nutrient intake of pregnant diabetic women and compare with RDA

3) To analyze the data statistically

\section{MATERIAL AND METHODS :-}

For present study, purposive random sampling technique was used to select the sample. By using this method, researcher selected total 500 pregnant diabetic women from Nagpur city. Data was collected by using questionnaire cum interview technique.72 hours recall method was used to collect the data regarding food habits, meal pattern and daily food intake. The nutrient intake was calculated using 'Indian Food Composition Table', by Longvah et al., (2017) and daily mean nutrient intake was compared with RDA(2010). The collected data was analysed by using descriptive statistics, which include one sample $Z$-test statistics. The confidence interval was kept 0.05 .

\section{OBSERVATION:}

Table 1: Food habits of pregnant diabetic women

\begin{tabular}{|l|l|l|}
\hline Food Habits & Number & Percent \\
\hline Vegetarian & 173 & 34.6 \\
\hline Non-Vegetarian & - & - \\
\hline Mixed & 327 & 65.4 \\
\hline Total & 500 & 100 \\
\hline
\end{tabular}

Table 1 illustrates information pertaining food habits of pregnant diabetic women. It was apparent from the information that $65.4 \%$ women consume both vegetarian as well as non-vegetarian food. Furthermore, $34.6 \%$ were pure vegetarian; however, no pregnant diabetic women found pure nonvegetarian. This shows that most of the pregnant diabetic women were consume both veg as well as non-veg food.

Vegetarian and vegan diets have increased worldwide in the last decades, according to the knowledge that they might prevent coronary heart disease, cancer, and type 2 diabetes. Althought plant-based diets are at risk of nutritional deficiencies such as proteins, iron, vitamin $\mathrm{D}$, calcium, iodine, omega-3, and vitamin B12, the available evidence shows that well planned vegetarian and vegan diets may be considered safe during pregnancy and lactation, but they require a strong awareness for a balanced intake of key nutrients (Sebastiani,)

Table 2: Meal pattern of pregnant diabetic women

\begin{tabular}{|l|l|l|}
\hline Meal Pattern & Number & Percent \\
\hline Breakfast- Lunch- Breakfast-Dinner & 44 & 8.8 \\
\hline Breakfast- Lunch- Dinner & 315 & 63.0 \\
\hline Lunch- Breakfast-Dinner & 12 & 2.4 \\
\hline Lunch-Dinner & 129 & 25.8 \\
\hline Total & 500 & 100 \\
\hline
\end{tabular}

Table 2 demonstrates information pertaining to meal pattern of pregnant diabetic women. It was apparent that $63.0 \%$ pregnant diabetic women followed breakfast-LunchDinner meal pattern.

Table 3: Daily nutritional Intake of pregnant diabetic women

\begin{tabular}{|c|c|c|c|c|c|}
\hline Nutrient & $\begin{array}{l}\text { Mean } \\
\text { Daily } \\
\text { Intake }\end{array}$ & S.D. & RDA & $\mathbf{z}$ & $\mathbf{P}$ \\
\hline $\begin{array}{l}\text { Calorie } \\
\text { (Kcal) }\end{array}$ & 2339 & $\begin{array}{l} \pm 231.3 \\
8\end{array}$ & 2250 & 8.601 & $\begin{array}{l}0.000 \\
(<0.05)\end{array}$ \\
\hline $\begin{array}{l}\text { Protein } \\
\text { (gm) }\end{array}$ & 63.54 & \pm 9.48 & 82.2 & 44.014 & $\begin{array}{l}0.000 \\
(<0.05)\end{array}$ \\
\hline $\begin{array}{l}\text { Carbohyd } \\
\text { rate (gm) }\end{array}$ & 202.9 & \pm 34.3 & - & - & - \\
\hline Fat (gm) & 42.33 & \pm 10.6 & 30 & 26.01 & $\begin{array}{l}0.000 \\
(<0.05) \\
\end{array}$ \\
\hline Fibre (gm) & 12.55 & \pm 1.75 & - & - & - \\
\hline $\begin{array}{l}\text { Calcium } \\
\text { (mg) }\end{array}$ & $\begin{array}{l}557.0 \\
2\end{array}$ & \pm 28.26 & 1200 & 508.757 & $\begin{array}{l}0.000 \\
(<0.05)\end{array}$ \\
\hline Iron (mg) & 21.22 & \pm 9.43 & 35 & 32.676 & $\begin{array}{l}0.000 \\
(<0.05)\end{array}$ \\
\hline $\begin{array}{l}\text { Vitamin-A } \\
\text { (mg) }\end{array}$ & $\begin{array}{l}1509 . \\
11 \\
\end{array}$ & $\begin{array}{l} \pm 775.5 \\
3 \\
\end{array}$ & 6400 & 141.018 & $\begin{array}{l}0.000 \\
(<0.05)\end{array}$ \\
\hline $\begin{array}{l}\text { Vitamin } \\
\text { B1 (mg) }\end{array}$ & 0.053 & \pm 0.045 & 1.2 & 569.949 & $\begin{array}{l}0.000 \\
(<0.05)\end{array}$ \\
\hline $\begin{array}{l}\text { Vitamin } \\
\text { B2 (mg) }\end{array}$ & 0.12 & \pm 0.11 & 1.4 & 260.197 & $\begin{array}{l}0.000 \\
(<0.05)\end{array}$ \\
\hline $\begin{array}{l}\text { Vitamin C } \\
\text { (mg) }\end{array}$ & $\begin{array}{l}64.80 \\
5\end{array}$ & \pm 11.25 & 60 & 9.55 & $\begin{array}{l}0.000 \\
(<0.05)\end{array}$ \\
\hline $\begin{array}{l}\text { Folic Acid } \\
\text { (mg) }\end{array}$ & 120.4 & \pm 23.28 & 500 & 364.61 & $\begin{array}{l}0.000 \\
(<0.05)\end{array}$ \\
\hline $\begin{array}{l}\text { Vitamin } \\
\text { B12 (mg) }\end{array}$ & 0.07 & \pm 0.05 & 1.2 & 505.351 & $\begin{array}{l}0.000 \\
(<0.05) \\
\end{array}$ \\
\hline $\begin{array}{l}\text { Magnesiu } \\
\text { m (mg) }\end{array}$ & $\begin{array}{l}105.5 \\
7 \\
\end{array}$ & \pm 17.15 & 310 & 266.542 & $\begin{array}{l}0.000 \\
(<0.05) \\
\end{array}$ \\
\hline Zinc (mg) & 7.42 & \pm 1.98 & 12 & 51.729 & $\begin{array}{l}0.000 \\
(<0.05)\end{array}$ \\
\hline
\end{tabular}

S.D.- Standard Deviation; RDA- Recommended Dietary Allowance; $Z-Z$ value; P-P value

Above Table 1 illustrates information pertaining to daily nutrient intake of pregnant diabetic women in Nagpur city. It is evident that-

Average daily calorie intake of pregnant diabetic women was $2339 \pm 231.38$ Kcal, which is significantly $(Z=8.601 ; \mathrm{P}<0.05)$ more than $\mathrm{RDA}$ of calorie $(2250 \mathrm{Kcal})$ for pregnant women. Average daily protein intake of pregnant diabetic women was $63.54 \pm 9.48 \mathrm{gm} /$ day, which is substantially $(\mathrm{Z}=44.014 ; \mathrm{P}<0.05)$ less than RDA of protein $(82.2$ 
gm/day) for pregnant women. Average daily carbohydrate intake of pregnant diabetic women was $202.9 \pm 34.3 \mathrm{gm} /$ day. Average daily fat intake of pregnant diabetic women was $42.33 \pm 10.6 \mathrm{gm} /$ day, which is considerably $(Z=26.01 ; P<0.05)$ more than RDA of fat (30 gm/day) for pregnant women. Average daily fibre intake of pregnant diabetic women was $12.55 \pm 1.75 \mathrm{gm} /$ day.

Average daily calcium intake of pregnant diabetic women was $557.02 \pm 28.26 \mathrm{mg} /$ day, which is noticeably $(Z=508.757 ; \mathrm{P}<0.05)$ less than RDA of calcium (1200 mg/day) for pregnant women. Average daily iron intake of pregnant diabetic women was $21.22 \pm 9.43 \mathrm{mg} /$ day, which is noticeably $(Z=32.676 ; \mathrm{P}<0.05)$ less than $\mathrm{RDA}$ of iron (35 mg/day) for pregnant women.

Average daily vitamin-A intake of pregnant diabetic women was $1509.11 \pm 775.53 \square \mathrm{g} /$ day, which is significantly $(Z=141.018 ; \mathrm{P}<0.05)$ less than RDA of Vitamin-A (6400 $\square \mathrm{g} /$ day) for pregnant women. Average daily Vitamin- $B_{1}$ intake of pregnant diabetic women was $0.053 \pm 0.045 \mathrm{mg} /$ day, which is substantially $(Z=569.949$; $P<0.05)$ less than RDA of Vitamin-B $_{1}(1.2 \mathrm{mg} /$ day $)$ for pregnant women. Average daily Vitamin-B $\mathrm{B}_{2}$ intake of pregnant diabetic women was $0.12 \pm 0.11 \mathrm{mg} /$ day, which is considerably $(Z=260.197 ; \mathrm{P}<0.05)$ less than RDA of Vitamin-B2 (1.4 mg/day) for pregnant women. Average daily Vitamin-C intake of pregnant diabetic women was $64.805 \pm 11.25 \mathrm{mg} /$ day, which is considerably $(Z=9.55 ; \mathrm{P}<0.05)$ more than RDA of Vitamin-C $(60 \mathrm{mg} /$ day $)$ for pregnant women. Average daily folic acid intake of pregnant diabetic women was $120.4 \pm 23.28 \square \mathrm{g} /$ day, which is significantly $(Z=364.61 ; \mathrm{P}<0.05)$ less than RDA of folic acid (500 $\square \mathrm{g} /$ day) for pregnant women. Average daily Vitamin-B ${ }_{12}$ intake of pregnant diabetic women was $0.07 \pm 0.05 \square \mathrm{g} /$ day, which is significantly $(Z=505.351 ; \mathrm{P}<0.05)$ less than RDA of Vitamin-B 12 (1.2 $\square \mathrm{g} /$ day) for pregnant women.

Average daily magnesium intake of pregnant diabetic women was $105.57 \pm 17.15 \mathrm{mg} /$ day, which is considerably $(Z=266.542 ; \mathrm{P}<0.05)$ less than RDA of magnesium (310 mg/day) for pregnant women. Average daily zinc intake of pregnant diabetic women was $7.42 \pm 1.98 \mathrm{mg} /$ day, which is considerably $(Z=51.729 ; \mathrm{P}<0.05)$ less than RDA of zinc (12 mg/day) for pregnant women.

\section{CONCLUSION:}

A dietary survey of pregnant diabetic women was carried out and nutrient intake was calculated from three-day dietary recall of these women. It is apparent from the results that pregnant diabetic women get calories and fats more than they required. Furthermore, it is also noticed that there is lack of required amount of protein, calcium, iron, vitamin-A, vitamin- $\mathrm{B}_{1}$, vitamin- $\mathrm{B}_{2}$, folic acid, vitamin- $\mathrm{B}_{12}$, magnesium and zinc in their diet.

They follow B-L-D (breakfast-lunch-dinner) method of diet. Very less no. of diabetic pregnant women consume milk and milk products in their diet while more no. of diabetic pregnant women consume fruits and green leafy vegetables in their diet but it is not significant.

Diabetic pregnant women get higher amount of calories, carbohydrate and fats from their diet while get less amount of proteins, vitamin-A, calcium, iron, magnesium and zinc.

It is suggested that Diabetic pregnant women should consult a dietician and get a weekly diet chart. The diet chart should be followed strictly; they should take timely breakfast and meals, should strictly avoid eating fast food and should use fruits and green leafy vegetables in their diet. .

\section{REFERENCES:-}

American Diabetes Association: Evidence-based nutrition principles and recommendations for the treatment and prevention of diabetes and related complications. Diabetes Care 2002, 25:202-212.

Longvah, T., Ananthan, R., Bhaskarachary, K. and Venkaiah. (2017). Indian Food Composition Tables, National Institute of Nutrition.

Pérez-Ferre, N. Valle, L.D., Torrejón, M.J., Barca, I., Calvo, M.I., Matía, P., Rubio, M.A., and CallePascual, A.L. (2015) Diabetes mellitus and abnormal glucose tolerance development after gestational diabetes: A three-year, prospective, randomized, clinical-based, Mediterranean lifestyle interventional study with parallel groups, Clinical Nutrition, 34(4):579-585

Rogozińska, E., Chamillard, M., Hitman, G.A., Khan, K.S. and Thangaratinam, S. (2015). Nutritional Manipulation for the Primary Prevention of Gestational Diabetes Mellitus: A Meta-Analysis of Randomised Studies. PLOS ONE 10(2): e0115526.

Sebastiani, G., Barbero, A.H., Borrás-Novell, C., Casanova, M.A., Aldecoa-Bilbao, V., AndreuFernández, V., Tutusaus, M.P., Martínez, S.F., Dolores, M., Roig, G and García-Algar, O. (2019). The Effects of Vegetarian and Vegan Diet during Pregnancy on the Health of Mothers and Offspring, Nutrients, $11(3): 557$. 